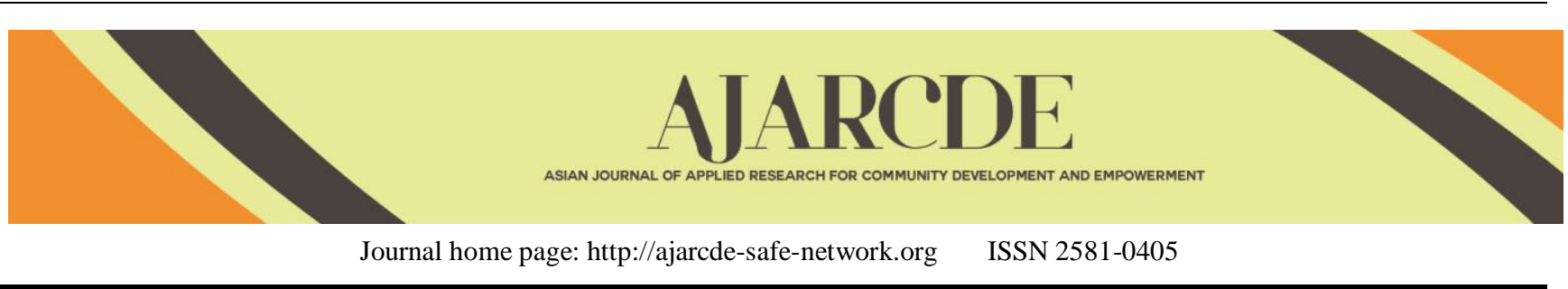

\title{
Characteristics of Jelly Candy made from Soybean Milk and the Addition of Eggshell Powder
}

Novelina, Tuty Anggraini, and Lailita Nurrahmi Putri

${ }^{1}$ Department of Agricultural Processing Technology, Andalas University, Limau Manis, Padang, 25166, Indonesia

\begin{tabular}{l} 
ARTICLE INFO \\
\hline Article History: \\
Received: 12 January 20 \\
Final Revision: 17 March 20 \\
Accepted: 19 April 20 \\
Online Publication: 20 April 20 \\
KEYWORDS \\
\hline Chicken eggshells, soymilk, jelly candy, \\
CORRESPONDING AUTHOR \\
\hline E-mail: \\
novelina@ae.unand.ac.id//novelinasutanto@ yahoo.com
\end{tabular}

\section{INTRODUCTION}

\subsection{Research Background}

Jelly candy is processed from hydrocolloid components such as agar, gum, pectin, starch, carrageenan, gelatin, etc. which are used for texture modification to produce a chewy product, can be printed and processed aging before packaging [1]. In the manufacture of jelly candy, generally added fruit juice or essense to provide a distinctive color or flavor, as well as add nutritional value of the jelly candy. Apart from juice other ingredients such as milk can also be used. In this research soybean milk is used in the process of making jelly candy. Soy milk was chosen because it has a distinctive aroma and taste and high nutritional value.

Soy milk has a protein content that is almost the same as cow's milk. However, the perfection and completeness of the components of cow's milk food is still better. The weakness of this soy milk is the lack of mineral content, especially calcium [2]. Calcium levels in 100 grams of soy milk only about $15 \mathrm{mg}$ [3]. The availability of calcium in the body is very important because of its main role in the formation of bones and teeth [4]. Therefore in this study the addition of calcium to soybean milk jelly candy is made, so that the resulting jelly candy has a higher calcium content. Calcium used comes from chicken eggshell waste that is obtained through the process of sterilization, drying, and downsizing.

So far, the potential for eggshell waste in Indonesia is quite large. Eggshells are rich in mineral salts, the highest minerals in eggshells are calcium carbonate $(98.43 \%)$, magnesium carbonate $(0.84 \%)$ and calcium phosphate $(0.75 \%)$. Calcium from eggshells serves to increase the mineral density in bones for osteoporosis sufferers [5].

\subsection{Research Objective}

This study aimed to determine the appropriate addition of chicken eggshell powder to the best characteristics of soy milk jelly candies and to determine consumer acceptance.

\section{MATERIALS AND METHODS}

\subsection{Materials and Equipments}

The raw materials used in this study were wilis soybean varieties, chicken eggs, sugar (sucrose), carrageenan and konjac iota. The chemicals used in this study were, distilled water, indicator methylene red-methylene blue, $\mathrm{H}_{2} \mathrm{SO}_{4} 25 \%$, $\left(\mathrm{NH}_{4}\right)$ $2 \mathrm{HPO}_{4} 10 \%$, Pb-acetate, Luff Schoorl solution, Sodium tio 
sulfate $0.1 \mathrm{~N}, 0.5$ starch solution $\%$, buffered peptone water, phenolphthalein indicator, $\mathrm{NaOH} 0.1 \mathrm{~N}, \mathrm{~K}_{2} \mathrm{SO}_{4}$, concentrated $\mathrm{H}_{2} \mathrm{SO}_{4}, \mathrm{HCl} 3 \mathrm{~N}$, lanthanum oxide $\left(\mathrm{La}_{2} \mathrm{O}_{3}\right), \mathrm{Na}_{2} \mathrm{~S}_{2} \mathrm{O}_{3}, \mathrm{H}_{3} \mathrm{BO}_{3}$, trisodium citrate solution, Tetrathionate broth (TTB), Xylose lysine desoxychate $\left(\mathrm{La}_{2} \mathrm{O}_{3}\right)$, trisodium citrate solution, Tetrathionate broth (TTB), Xylose lysine desoxychate), Hektoen enteric agar (HE), Bismuth sulfite agar (BSA), lactose broth, DPPH solution, methanol. Meanwhile, the equipment used consists of tools for the manufacture of products and for the analysis of jelly candies: analytical scales, ovens, $\mathrm{pH}$ meters, aw meter, spectrophotometers, HPLC, AAS, autoclaves and glassware.

\subsection{Design Experiment}

The study design was a completely randomized design (CRD) with five treatments and three replications. The observational data were analyzed statistically by the $\mathrm{F}$ test and if the pilgrimage test showed real differences, then continued with the Duncan's New Multiple Range Test (DNMRT) at 5\% significance level. The treatments in this study were: $\mathrm{A}=$ control (without the addition of eggshell powder) and addition of eggshell powder, respectively: $\mathrm{B}=0.2 \% ; \mathrm{C}=0.4 \% ; \mathrm{D}=0.6 \%$; and $\mathrm{E}=0.8 \%$

\subsection{Research Implementation}

\subsubsection{Reducing the Size of the Eggshell [6]}

The eggshells are washed thoroughly, then boiled for 15 minutes. After that, it is dried for 2 hours at $60 \mathrm{oC}$. After that, it is ground with a blender and sieved with a 100 mesh sieve.

\subsubsection{Soymilk Production [3]}

Soybean seeds are cleaned of dirt, gravel, sand, pieces of twigs and soybean stems. Damaged, black and mustard soybean seeds must be removed. After that the seeds are washed thoroughly. Floating dirt and seeds must be removed. Washing is done until the rinse water looks clear. Washed soybean seeds soaked in water for 8 hours and drained.

Hot water $\left(85-90^{\circ} \mathrm{C}\right)$ is prepared for grinding, the temperature is maintained throughout the work. The amount of water is 3 times the weight of dry soybeans. Soybean seeds are blended with a blender until they become soybean porridge. Milling is done while adding hot water. Then the soybean porridge is filtered. The liquid obtained is called raw soy milk, then boiled.

\subsubsection{Soymilk Jelly Candy Production [7]}

Water, sucrose, HFS, konjac, and carrageenan iota are mixed and stirred until dissolved with a spoon, then add eggshell powder according to treatment and stir until evenly distributed. Furthermore, it is heated over low heat for 5 minutes until it reaches a temperature of $80-85^{\circ} \mathrm{C}$ while continuing to stir until a gel is formed, then when the temperature begins to drop soybean milk is added while continuing to stir until mixed. The dough is then printed in a baking dish and allowed to stand at room temperature $\left(25-27^{\circ} \mathrm{C}\right)$ until it is cold and the gel solids, after solidifying the cutting is done. Then put in the oven temperature of $50^{\circ} \mathrm{C}$ for 14 hours. After that the milk jelly candy is removed from the oven and let stand at room temperature until it is cold and packaged.

\subsection{Observation}

Observations made on raw materials were made on eggshell powder, namely yield, Salmonella test, calcium content, protein content. While observations of soy milk jelly candy products with the addition of eggshells include observations of $\mathrm{pH}$, water content, ash content, reducing sugar, saccharose, calcium levels, protein content, aw values, and gel strength, total plate counts, and organoleptic tests which include taste, aroma, color, texture, and mouthfeel.

\section{RESULT AND DISCUSSION}

\subsection{Eggshell Powder}

Eggshell powder which was added to soymilk jelly candy is smaller than 100 Mesh, does not contain Salmonella (negative), calcium content is $38.46 \%$, and protein content is $1.02 \%$. Test results for Salmonella bacteria have fulfilled the requirements set by Ref. [1]. Salmonella is a mesophilic bacterium, can grow in the temperature range of $5-460 \mathrm{C}$ with an optimum growth temperature of $35-37^{\circ} \mathrm{C}$, and these bacteria will die at pasteurization temperatures [8]. The yield of powder was $41.87 \%$, because the sifter that did not pass the sieve was quite high.

\section{2. $\quad$ Standard Characteristics of Jelly Candy}

The soymilk jelly candies are tested based on several important characteristics specified in Ref. [1] regarding the quality requirements for soft candies (Table 1).

Table 1. Average Water Content, Ash Content, Reducing Sugar and Saccharose in Soymilk Jelly Candy

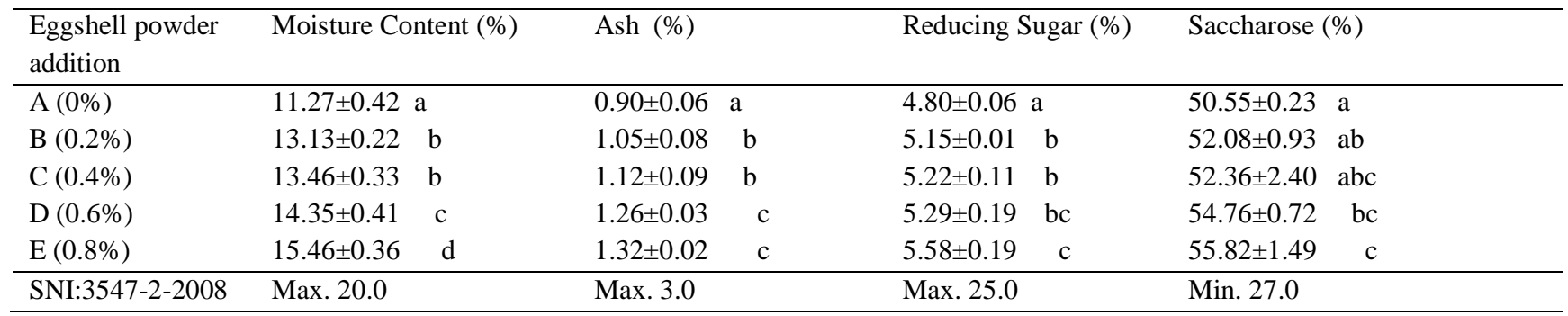

Note: Figures in columns followed by unequal lowercase letters, differ markedly according to the DNMRT test at 5\% significance level.

Based on Table 1 it can be seen that all of the quality parameters of soy milk jelly candy have met the requirements of Ref. [1]. although each treatment of adding eggshell powder was significantly different from each other ..

\subsubsection{Moisture Content}

Gelling is a phenomenon or cross-linking polymer chains to form a continuous three-dimensional mesh. Furthermore, this net 
can capture or immobilize the water in it so that it can form a strong and rigid structure. Increased water content of soy milk jelly candy is directly proportional to the increase in $\mathrm{pH}$ due to the addition of eggshells. According to Ref. [9], the higher the $\mathrm{pH}$ of jelly candy from the optimal $\mathrm{pH}$ of gel formation, the gel's ability to trap water will decrease because the bonds between the hydrocolloid polymer chains become weak. Similarly (Atmaka, Nurhartadi, \& Karim, 2013), gels from a mixture of carrageenan and konjac can be formed at $80 \mathrm{oC}$ at a $\mathrm{pH}$ of 5.63-5.70. It is seen that the $\mathrm{pH}$ of gel formation in this study is very far compared to the $\mathrm{pH}$ of soy milk jelly candies in this study which ranged from 7.32 to 8.75 (Table 2). Also in this study the $\mathrm{pH}$ of soy milk jelly candies is getting closer to the maximum stability $\mathrm{pH}$ of carrageenan which is 9 [10]. This is thought to cause the gel's reduced ability to trap water, so the calculated water content is higher.

\subsubsection{Ash content}

Ash is an inorganic residue that is obtained by ashing or heating at high temperatures above $450 \mathrm{oC}$ and by reducing the organic components with strong acids. The higher the rate of addition of eggshells, the higher the ash content of soy milk jelly candy (Table 1). Based on research by Ref. [11], mineral content in chicken eggshell powder consists of calcium (Ca) of $401 \pm 7.2$ grams or about $39 \%$ calcium, in the form of calcium carbonate. There is also strontium ( $\mathrm{Sr}$ ) of $372 \pm 161 \mu \mathrm{g}$, and minerals $\mathrm{V}, \mathrm{B}$, $\mathrm{Fe}, \mathrm{Zn}, \mathrm{P}, \mathrm{Mg}, \mathrm{N}, \mathrm{F}, \mathrm{Se}, \mathrm{Cu}$, and $\mathrm{Cr}$ in small amounts.

\subsubsection{Reducing Sugar Levels}

Reducing sugar levels are related to the process of inversion of sucrose into inverted sugar (glucose and fructose), and this process can be influenced by temperature or $\mathrm{pH}$ [12]. The acidity $(\mathrm{pH})$ of soymilk jelly candies produced is in the range of 7.328.75. According to Ref. [13], sucrose can be degraded at weak base $\mathrm{pH}$ (starting at $\mathrm{pH} 8.3$ ), which subsequently causes an increase in fructose levels. Meanwhile according to Ref. [12], at pH 5-11 the reducing sugar content is relatively stable.

\subsubsection{Saccharose Content}

Saccharose Content for all treatments met the quality requirements of soft confectionery according to Ref. [1] at a minimum of $27.0 \%$ (Table 1). According to Ref. [14], sucrose during processing can experience thermal degradation as well as degradation under acidic or basic conditions. This degradation can result in the formation of various volatile components, including aldehydes, furans, and alcohols, as well as producing chocolate acids and polymer pigments.

\subsection{Physicochemical and Microbiological Characteristics of Jelly Candy}

The results of the analysis of protein and calcium levels and the observation of jelly candy $\mathrm{pH}$ can be seen in Table 2 . The results of analysis of variance showed that the addition of eggshell flour did not significantly affect the protein content, but it did have a significant effect on the calcium content and $\mathrm{pH}$.

Table 2. Physicochemical and Microbiological Characteristics of Jelly Candy

\begin{tabular}{llllll}
\hline Parameter & \multicolumn{2}{l}{ Eggshell powder addition } & & \\
& $\mathrm{A}(0 \%)$ & $\mathrm{B}(0,2 \%)$ & $\mathrm{C}(0,4 \%)$ & $\mathrm{D}(0,6 \%)$ & $\mathrm{E}(0,8 \%)$ \\
\hline Calcium (\%) & $0.20 \pm 0.01^{\mathrm{a}}$ & $0.29 \pm 0.00^{\mathrm{b}}$ & $0.32 \pm 0.00^{\mathrm{c}}$ & $0.35 \pm 0.01^{\mathrm{d}}$ & $0.51 \pm 0.01^{\mathrm{e}}$ \\
Protein (\%) & $2.82 \pm 0.16^{\mathrm{a}}$ & $2.92 \pm 0.02^{\mathrm{a}}$ & $2.92 \pm 0.10^{\mathrm{a}}$ & $2.93 \pm 0.08^{\mathrm{a}}$ & $2.93 \pm 0.11^{\mathrm{a}}$ \\
$\mathrm{pH}$ & $7.32 \pm 0.25^{\mathrm{a}}$ & $8.17 \pm 0.16^{\mathrm{b}}$ & $8.45 \pm 0.15^{\mathrm{bc}}$ & $8.61 \pm 0.15^{\mathrm{c}}$ & $8.75 \pm 0.11^{\mathrm{c}}$ \\
Water Activity (aw) & $0.75 \pm 0.02^{\mathrm{a}}$ & $0.76 \pm 0.04^{\mathrm{a}}$ & $0.76 \pm 0.01^{\mathrm{a}}$ & $0.77 \pm 0.01^{\mathrm{a}}$ & $0.78 \pm 0.00^{\mathrm{a}}$ \\
Gel Strength (N/cm $\left.{ }^{2}\right)$ & $374.21 \pm 24.92^{\mathrm{b}}$ & $373.95 \pm 45.68^{\mathrm{b}}$ & $355.12 \pm 66.04^{\mathrm{ab}}$ & $281.07 \pm 38.20^{\mathrm{a}}$ & $269.17 \pm 47.47^{\mathrm{a}}$ \\
Total Plate Count & $7.5 \times 10^{2}$ & $2.7 \times 10^{2}$ & $2.1 \times 10^{2}$ & $1.1 \times 10^{2}$ & $3.1 \times 10^{2}$ \\
(cfu) & & & & &
\end{tabular}

Note: Figures in columns followed by unequal lowercase letters, differ markedly according to the DNMRT test at 5\% significance level

\subsubsection{Calcium Content}

The calcium content of soy milk jelly candies has increased along with the increase in the number of eggshells. This is because the eggshell contains calcium which is quite high in number, the calcium content in the eggshell is $38.46 \%$ of the total ash. Besides that calcium is also derived from soy milk and konjac used. According to Ref. [3] 100 grams of soy milk contains $15 \mathrm{mg}$ of calcium $(0.015 \%)$. Furthermore according to Ref. [4], edible konjac contains calcium which can be utilized by the human body.

\subsubsection{Protein content}

Based on the results of data analysis, it can be seen that the addition of eggshells does not have a significant effect on the protein content of soy milk jelly candy. This can be caused by the number of concentrations of eggshell addition in each treatment is small, while the protein content in the eggshell is also small.
Protein content in eggshells based on raw material test results is only $1.02 \%$.

\subsubsection{Degree of Acidity $(p H)$}

The higher concentration of eggshell addition, the $\mathrm{pH}$ of soy milk jelly candy will increase, this is caused by the high content of calcium carbonate in the eggshell. A high amount of calcium carbonate will increase the $\mathrm{pH}$ of the jelly candy. The carbonate group will bind to the $\mathrm{H}+$ ions contained in a solution derived from free amino acids to form $\mathrm{H}_{2} \mathrm{CO}_{3}$ which releases water and $\mathrm{CO}_{2}$ so that the concentration of $\mathrm{H}+$ ions in the solution decreases and the $\mathrm{pH}$ of the solution rises [9].

\subsubsection{Gel Strength}

The strength value of the gel indicates the amount of force applied by the probe to the jelly candy surface area. The greater the number obtained, the greater the force applied to the product, meaning that the strength of the gel is higher [15]. The higher 
the strength value of the gel, the more springy and elastic the resulting jelly candy.

The strength of soy milk jelly gel decreases with increasing eggshell concentration. This is related to the water content of jelly candy which is increasing along with the increase in the addition of eggshell concentration. According to Ref. [15], the strength of the gel is influenced by the free water content contained in the gel. The less free water content, the strength of the gel will increase. Based on research by Ref. [16] that tested the strength of jelly candy gel from cone skin gelatin, carrageenan and seaweed, the gel strength of the jelly candy ranged from 46.75 $169.35 \mathrm{~N} / \mathrm{cm}^{2}$.

\subsubsection{Water Activities (aw)}

Based on the results of data analysis showed that the addition of eggshells did not have a real effect on the value of aw soy milk jelly candy, but there was a tendency to increase in numbers. This is in accordance with research by Ref. [17] which shows the relationship between water content and aw value, through the tendency that the higher the water content, the higher the aw value.

Food products that have a water content between $10-40 \%$ and water activity (aw) between $0.60-0.85$ are included in the semiwet food group. This type of semi-wet food can be eaten immediately without rehydration and is stable during storage. Foodstuffs that have aw 0.70 are considered to be quite good and resistant during storage [18] aw of soy milk jelly candies ranging from 0.75 to 0.78 belong to the semi-wet food group.

\subsubsection{Total Microbes}

The observation shows that the total number of plates in soy milk jelly candy is smaller than the quality requirements for soft confectionery (jelly) at Ref. [1] which is a maximum of 5 x 104 $\mathrm{CFU} / \mathrm{mL}$. This is because jelly candy products contain high sugar, sugar will bind water that can be used by microbes for growth so it cannot be used by microbes. Judging from the range of aw values of soy milk jelly candy that is 0.75 to 0.78 , it is still below the aw value for bacterial or yeast growth whose minimum aw value for growth is $0.80-0.90$ [19]. To protect jelly candies from microbial contamination and extend shelf life, proper packaging is required. Semi-wet food (such as jelly candy) can be packaged with plastic or aluminum coating to prevent the entry of gases and water vapor [18].

\subsection{Organoleptic Value of Jelly Candy}

The average panelist acceptance of soy milk jelly candies through organoleptic tests on the taste, aroma, color, mouthfeel, and texture (elasticity) of jelly candies can be seen in Table 3

Table 3. Panelist Acceptance of Soymilk Jelly Candy

\begin{tabular}{llllll}
\hline \multirow{2}{*}{$\begin{array}{l}\text { Treatm } \\
\text { ent }\end{array}$} & \multicolumn{5}{l}{ Panelist Acceptance } \\
\cline { 2 - 6 } & Flavor & Aroma & Color & Texture & Mouthfeel \\
\hline A & 3.64 & 3.32 & 3.64 & 3.32 & 3.68 \\
B & 3.64 & 3.44 & 3.64 & 3.52 & 3.76 \\
C & 3.48 & 3.36 & 3.64 & 3.68 & 3.64 \\
D & 3.52 & 3.24 & 3.52 & 3.56 & 3.48 \\
E & 3.96 & 3.44 & 3.56 & 3.64 & 3.64 \\
\hline
\end{tabular}

Note: Organoleptic scores include $1=$ very dislike, $2=$ dislike, $3=$ ordinary, $4=$ like, $5=$ very like.

\subsubsection{Taste}

The highest assessment of taste was in treatment $\mathrm{E}(0.4 \%$ eggshell addition), which was 3.96 (Table 3). According to Ref. [9], the content of calcium carbonate (from eggshells) in fortified products can give a chalky taste, the chalky taste can mask (neutralize) the high sweetness of sucrose so that the jelly candy becomes more acceptable consumer. In this study the addition of eggshells only gave a little chalky taste to soy milk jelly candy. And the chalky taste slightly reduces the sweetness of the resulting soy milk jelly candy. That might be the cause of soy milk jelly candies with the highest concentration of eggshell addition received the best ratings by panelists in terms of taste.

\subsubsection{Aroma}

The highest assessment of taste was in treatments $\mathrm{B}$ and $\mathrm{E}$ (addition of eggshell $0.1 \%$ and $0.4 \%$ ), which was 3.44 for both. The addition of eggshells did not have a significant effect on the aroma of soy milk jelly candy. The fishy smell that may be caused by the eggshell is not detected in soy milk jelly candy. Seen from the treatment $\mathrm{E}$ which is the highest eggshell addition treatment, it is one of the products with the highest acceptance from panelists.

\subsubsection{Color}

The color of soy milk jelly candy is quite difficult to distinguish by panelists, because the difference looks not too significant. But if you pay close attention, it can be seen that the soy milk jelly candy with the addition of eggshells is getting higher, the color is increasingly brownish yellow. This might be due to a Maillard reaction. The appearance of soy milk jelly candies produced can be seen in Figure 1 .

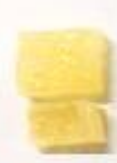

A

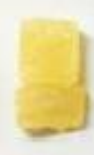

B

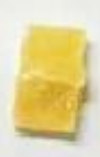

C
D

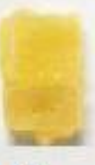

Figure 1 . Soy milk jelly candy color with the addition of various eggshell powder

\subsubsection{Texture (Elasticity)}

The highest assessment of texture (elasticity) was found in treatment $\mathrm{C}$ (addition of eggshell $0.2 \%$ ) in the amount of 3.68. According to Ref. [15], the higher the strength value of the gel, the more resilient and elastic the resulting jelly candy. Meanwhile, the results of testing the strength of the gel against soybean milk jelly candy, treatment A (without the addition of an eggshell) get the highest value that is equal to $374.21 \mathrm{~N} / \mathrm{cm}^{2}$. However, based on organoleptic tests, the best elasticity value according to panelists was in treatment $\mathrm{C}$, and the lowest value in treatment A. Organoleptically, the elasticity of soy milk jelly candy from each treatment was still not like commercial jelly candy, because it tends to break more easily when stretched.

\subsubsection{Mouthfeel}

Mouthfeel test (sandy impression) needs to be done, because to find out how panelists accept the possibility of sandy 
impression in jelly candies which are added with eggshells. The highest evaluation of mouthfeel was found in treatment B (addition of eggshell $0.1 \%$ ) in the amount of 3.76. Sandy impression of jelly candy due to the addition of eggshell has no effect because of the addition of concentration in small quantities and the eggshell used has been sieved into a very fine powder using a 100 mesh sieve, and during the processing of soy milk jelly candies, eggshells have been mixed evenly in gel formed.

\section{CONCLUSIONS}

The addition of eggshells with different concentrations have a significant effect on $\mathrm{pH}$, water content, ash content, saccharose levels, reducing sugar levels, calcium levels, gel strength, whereas protein content and aw values do not have a significant effect. Treatment of soy milk jelly $\mathrm{E}$ with the addition of $0.8 \%$ eggshell is the best product because in terms of organoleptic received by the panelists with an average acceptance of taste (3.96), aroma (3.44), color (3.56), texture (3.64), and mouthfeel (3.64). Its chemical composition also meets the SNI standard for soft confectionery (jelly), which has a water content of $15.46 \%$, ash content $1.32 \%$, saccharose content $50.55 \%$, reducing sugar $5.58 \%$, total plate number $3.1 \times 103 \mathrm{cf} / \mathrm{g}$, aw value of 0.78 . The value of gel strength is $269.17 \mathrm{~N} / \mathrm{cm}^{2}$, and has the highest calcium content, $0.51 \%$ and $2.93 \%$ protein content.

\section{REFERENCE}

[1] Badan Standardisasi Nasional. (2000). Batas Maksimum Cemaran Mikroba dan Batas Maksimum Residu Dalam Bahan Makanan Asal Hewan.

[2] Wulandari, D. A. (2004). Fortifikasi Tepung Tulang Rawan Ayam Pedaging pada Pembuatan Susu Kedelai Bubuk sebagai Sumber Kalsium.

[3] Cahyadi, W. (2012). Kedelai Khasiat dan Teknologi. Bumi Aksara. Jakarta

[4] Nagayama, S., Nakamura, A., Suzuki, K., \& Innami, S. (1975). Studies on Calcium in the Edible Konnyaku. The Japanese Journal of Nutrition and Dietetics. https://doi.org/10.5264/eiyogakuzashi.33.265

[5] Daengprok, W., Garnjanagoonchorn, W., Naivikul, O., Pornsinlpatip, P., Issigonis, K., \& Mine, Y. (2003). Chicken eggshell matrix proteins enhance calcium transport in the human intestinal epithelial cells, Caco-2. Journal of Agricultural and Food Chemistry. https://doi.org/10.1021/jf034261e

[6] Rahmawati, W. A., \& Nisa, F. C. (2015). Fortifikasi Kalsium Cangkang Telur pada Pembuatan Cookies (Kajian Konsentrasi Tepung Cangkang Telur dan Baking Powder). Universitas Brawijaya Malang. https://doi.org/10.1007/s40333-013-0248-x

[7] Azizah, N. H. (2012). Pembuatan Permen Jelly Dari Karagenan dan Konjak Dengan Aplikasi Prebiotik XiloOligosakarida. Institut Pertanian Bogor.

[8] Sopandi, T., \& Wardah. (2014). Mikrobiologi Pangan. Penerbit Andi.

[9] Lesmana, S. N., Putut, T. I., dan Kusumawati, N. (2008). Pengaruh Penambahan Kalsium Karbonat Sebagai Fortifikan Kalsium Terhadap Sifat Fisikokimia dan Organoleptik Permen Jeli Susu. Jurnal Teknologi Pangan Dan Gizi. https://doi.org/10.33508/JTPG.V7I1.148

[10] Kelco, C. P. (2001). GENU ® Carrageenan Book. cpkelco. Retrieved from http://foodsci.rutgers.edu/carbohydrates/Carrageenan Book.pdf
[11] Schaafsma, A., Pakan, I., Hofstede, G. J. H., Muskiet, F. A. J., Van Der Veer, E., \& De Vries, P. J. F. (2000). Mineral, amino acid, and hormonal composition of chicken eggshell powder and the evaluation of its use in human nutrition. Poultry Science. https://doi.org/10.1093/ps/79.12.1833

[12] Panpae, K., Jaturonrusmee, W., Mingvanish, W., Nuntiwattanawong, C., Chunwiset, S., Santudrob, K., \& Triphanpitak, S. (2008). Minimization of Sucrose Losses In Sugar Industry By $\mathrm{pH}$ and Temperature Optimization. The Malaysian Journal of Analytical Sciences, 12(2), 513-519.

[13] Eggleston, G. (2011). American Society of Sugar Cane Technologists 41st Annual Joint Meeting, New Orleans, Louisiana, USA, 8-10 June 2011.

[14] Yildiz, F. (2009). Advances in food biochemistry. Advances in Food Biochemistry.. CRC Press

[15] Kaya, A. O. W., Suryani, A., Santoso, J., \& Syahbana, M. (2015). The effect of gelling agent concentration on the characteristic of gel produced from the mixture of semirefined carrageenan and glukomannan. International Journal of Sciences: Basic and Applied Research, 20(1), 313-324.

[16] Suptijah, P., Suseno, S., \& Anwar, C. (2014). Analisis Kekuatan Gel (Gel Strength) Produk Permen Jelly Dari Gelatin Kulit Ikan Cucut Dengan Penabahan Karaginan dan Rumput Laut. Jurnal Pengolahan Hasil Perikanan Indonesia, 16(2), 183-191.

[17] Fiardilla, F. (2015). Pengaruh Penambahan Gelatin Sapi Terhadap Karakteristik Mutu Permen Jelly Pala (Mystirica fragrans, Houtt). Skripsi. Universitas Andalas

[18] Muchtadi, T. R., \& Sugiyono. (2013). Prinsip Proses dan Teknologi Pangan. ISBN: 9786027825413. Alfabeta, Bandung

[19] Winarno, F. (2004). Kimia Pangan dan Gizi. Jakarta: PT. Gramedia Pustaka Utama. 